Page: 362-372 ISBN: 978-602-6 988-75-1

Web Jurnal Online: jurnal.unmuhjember.ac.id

By: Hanantyo Sri Nugroho

Government Glocalization As An Public Service Innovation In Wukirsari Village,

Sleman Regency

\title{
GOVERNMENT GLOCALIZATION AS AN PUBLIC SERVICE INNOVATION IN WUKIRSARI VILLAGE, SLEMAN REGENCY
}

\author{
Hanantyo Sri Nugroho \\ (hanantyosrinugroho@amikom.ac.id) \\ Amikom
}

\begin{abstract}
The Population Data Collection System (Sidampak) in Wukirsari Village is a population administration service program that has provided many benefits. The background of the absence of a clear plan in the development of services to the community and the low level of community participation in ownership of population administration documents which later became the basis for creating a population administration service system that can provide complete, accurate, fast, easy and integrated results. This then gave rise to consequences for the Wukirsari village government in making public service innovations. The innovation is not only to the value of fast, easy, cheap, but more to the value of services that are tailored to the culture of Wukirsari society. One of them is the lukadesi program and my birthday program. The program then changed the innovation of public services more in accordance with the social conditions of the village community. This then became a pressure point for the activity of citizens in managing population administration in the village of Wukirsari. Meanwhile, the research method that will be used by researchers is a qualitative descriptive research method.

Keywords: Public Service, E-Government Glocalization, Population Data Collection System (Sidampak)
\end{abstract}


Proceeding ICOGISS 2019

Page: 362-372 ISBN: 978-602-6 988-75-1

Web Jurnal Online: jurnal.unmuhjember.ac.id

By: Hanantyo Sri Nugroho

Government Glocalization As An Public Service Innovation In Wukirsari Village,

Sleman Regency

\section{INTRODUCTION}

This study examines the elements and success factors of e-government glocalization as a public service innovation strategy. The target of this study is the Population Data Collection System Program (Sidampak) of the Wukirsari Village Government. This problem is interesting to study because of concerns about the inclusion of elements of globalization in local activities brought about by e-government policy. The anxiety that arises later is not to the anti-globalization values or to the process, but rather how to "localize" globalization. The "localization" meant here is how to adjust from the current of globalization to the social conditions of the community and the existing regulations in the area, which is usually called glocalization. Furthermore, regional innovation is a smart and genuine local policy and idea, in dealing with any form of limitation or optimizing every form of excellence that the region has (JPIP, 2017).

The Wukirsari village government is part of a local institution in Sleman Regency. Through the Population Data Collection System (Sidampak) Program, the Wukirsari village government is able to innovate public services based on the process of adjusting local institutions to the cultural values of e-government which is then contextualized to the needs of the Wukirsari village community, especially in the government sector. In understanding the innovation process, researchers use a newinstitutionalist perspective. New-institutionalis is a perspective in seeing an institution that places relationships between individuals and institutions. Furthermore, this research is also elaborated on the theory of accuracy, where not only institutions that influence agency behavior, but institutions are seen as dependent factors of the presence of agencies. Therefore, this can be seen how institutions can form individuals, and of course individuals can reshape existing institutions.

Furthermore, the consequence that emerged at the time of this study using a newinstitutionalist perspective was to look at the norms of the institutions in the Wukirsari village government. Furthermore, the institutional norms that can affect the Wukirsari village government are the supra-governmental environment, namely in the form of regional government, provincial government, central government, which have implemented the values of implementing digital-based governance in the first place. Meanwhile, the Government of Wukirsari Village has a distance from the sub-district government of $3 \mathrm{~km}$, with the district government $13 \mathrm{~km}$, and with the DIY government is $25 \mathrm{~km}$. This was then elaborated by how to observe the organization of Wukirsari village government institutions in providing public service innovations. The conditions of implementation are then seen from the aspects of significance and dominance of government institutions on the quality of public services. Later, the quality of public services can be assessed from (Permenpan, 2017):

a. Service policy.

Service policy indicators are seen from the availability of service standards, the process of drafting service standards has involved the community and stakeholders, available documentation about the service system established, service systems in accordance with the provisions of legislation, information on service standards that can be easily accessed, high involvement of service users . 
Proceeding ICOGISS 2019

Page: 362-372 ISBN: 978-602-6 988-75-1

Web Jurnal Online: jurnal.unmuhjember.ac.id

By: Hanantyo Sri Nugroho

Government Glocalization As An Public Service Innovation In Wukirsari Village,

Sleman Regency

b. HR professionalism

Indicators of professionalism are seen from the availability of service providers with competencies according to the needs of types of services, implementers of time-responsive services, alertness of implementers in providing services, available rules of conduct and code of ethics implementing services, awarding, sanctions, service culture.

c. Public Service Infrastructure

Indicators of public service facilities are seen from available parking spaces that are safe, comfortable and easily accessible, available waiting room facilities are convenient, special toilet facilities are available for service users, available facilities and infrastructure for service users, front office facilities available for consulting and information services direct face.

d. Public Service Information System

Indicators of public service information systems are seen from available public service information systems for public information, available public service information systems supporting service operations, available site ownership and site management, updating of data and information on sites, non-electronic information available that supports services.

e. Consultation and Complaints

Indicators of consultation and complaints are seen from the available facilities and media consulting services, available consultation documentation, available facilities and media for complaint services, available documentation of complaints.

f. Innovation

Indicators of innovation are seen from available innovations in providing public services.

In addition, this study also conducted an observation of the role of agencies in the Wukirsari village government. In this case, the role and position of the agency is the role of the actor who influences the changes that occur. Later, the diagnosis in looking at the role and position of the agency by using the framework of the 3 consciousnesses within the agency, namely unconsciousness, practical awareness, critical awareness.

Meanwhile, the research method that will be used by researchers is a qualitative descriptive research method. Descriptive qualitative methods, namely as research procedures that produce descriptive data in the form of written or oral words from people and observable behavior (Moleong, 2002). Whereas on the other hand, qualitative research methods emphasize attention to human actions, the process of forming actions, social interactions and others (Muhadjir, 2000). The initial stages of the study were carried out by mapping the problems, theories, and regulations relating to e-government and the Population Data Collection System Program (Sidampak). Therefore, this stage included internal discussions with the Wukirsari Village Government. It aims to look for regulations, documents, and other related references. Thus, the initial stages of this research can contribute to the next stage in the form of in-depth study of the focus and formulation of the problem in this study. In collecting data, this study collected data 
Proceeding ICOGISS 2019

Page: 362-372 ISBN: 978-602-6 988-75-1

Web Jurnal Online: jurnal.unmuhjember.ac.id

By: Hanantyo Sri Nugroho

Government Glocalization As An Public Service Innovation In Wukirsari Village,

Sleman Regency

through crossing various data sources originating from literature studies, observations and interviews. Furthermore, data reduction is done on the data that has been obtained by summarizing the data, sorting out the main points and focusing on the things that are related and also important to this research. Furthermore, the data analysis method used is interactive data analysis, namely analysis carried out in an interactive form on 3 (three) main components which are interrelated with each other (Milles, 1994):

a. Data reduction is interpreted as the process of selecting focus on simplifying, abstracting, and transforming "rough" data that appears from written records in the field.

b. Data presentation. This sub process is a form of "presentation" which is interpreted as a set of structured information that gives the possibility of drawing conclusions and taking action.

c. Draw conclusions or diversify. In this sub-process, researchers begin to interpret actions that are giving meaning to data or information that has been presented.

This analysis process goes on like a cycle. The researcher moves between the three. This is intended to understand and get a deep, comprehensive, and detailed understanding so as to produce conclusions as a result of understanding the researcher.

\section{DISCUSSION}

The Population Data Collection System (Sidampak) in Wukirsari Village is an innovation program for population administration services initiated in 2012. There are a number of issues that have led to the Sidakmpak program, namely (in an interview with Ma'ruf, 2019):

a. There are no clear targets and targets related to the development of services to the community.

b. The absence of population data base with high validity.

c. The absence of data processing is able to provide benefits in terms of product services, reports, and village statistics comprehensively.

d. Quality of service that does not meet the element of excellent service.

e. There is input from the public about satisfaction with population services in Wukirsari Village.

The background of the landscape is then used as the basis for creating a population administration service system that can provide complete, accurate, fast, easy and integrated results. This then gave rise to consequences for the Wukirsari village government in making public service innovations. The innovation is not only to the value of fast, easy, cheap, but more to the value of services that are tailored to the culture of Wukirsari society. One of them is the lukadesi program and my birthday program. The program then changed the innovation of public services more in accordance with the social conditions of the village community. This then became a pressure point for the activeness of residents in managing population administration in the village of Wukirsari (in an interview with Ma'ruf, 2019). Gradually with various improvements, the Sidampak 
Proceeding ICOGISS 2019

Page: 362-372 ISBN: 978-602-6 988-75-1

Web Jurnal Online: jurnal.unmuhjember.ac.id

By: Hanantyo Sri Nugroho Government Glocalization As An Public Service Innovation In Wukirsari Village, Sleman Regency

program can be fully used in 2014. The legal basis for implementing Sidampak innovation is:

a. Decree of the Village Head No.24 / KPTS.KADES / 2015 concerning Administrative Service Standards to the Community

b. Decree of the Village Head No.41 / KPTS.KADES / 2015 concerning the Use of the Data Utilization System for the Population Administration of Sidampak

c. Decree of the Village Head No.42 / KPTS.KADES / 2015 concerning the Implementation of the Death Deed Facilitation Program

Furthermore, the aim of the Sidampak system is to support the process of improving the quality of services to the community, internal village government, village institutions, stakeholders of Wukirsari Village, academic institutions and vertical agencies in terms of speed, accuracy and accuracy as well as improving the quality of public service administration and population administration in prime (Wukirsari, 2018). Following is the picture of the Sidampak program application

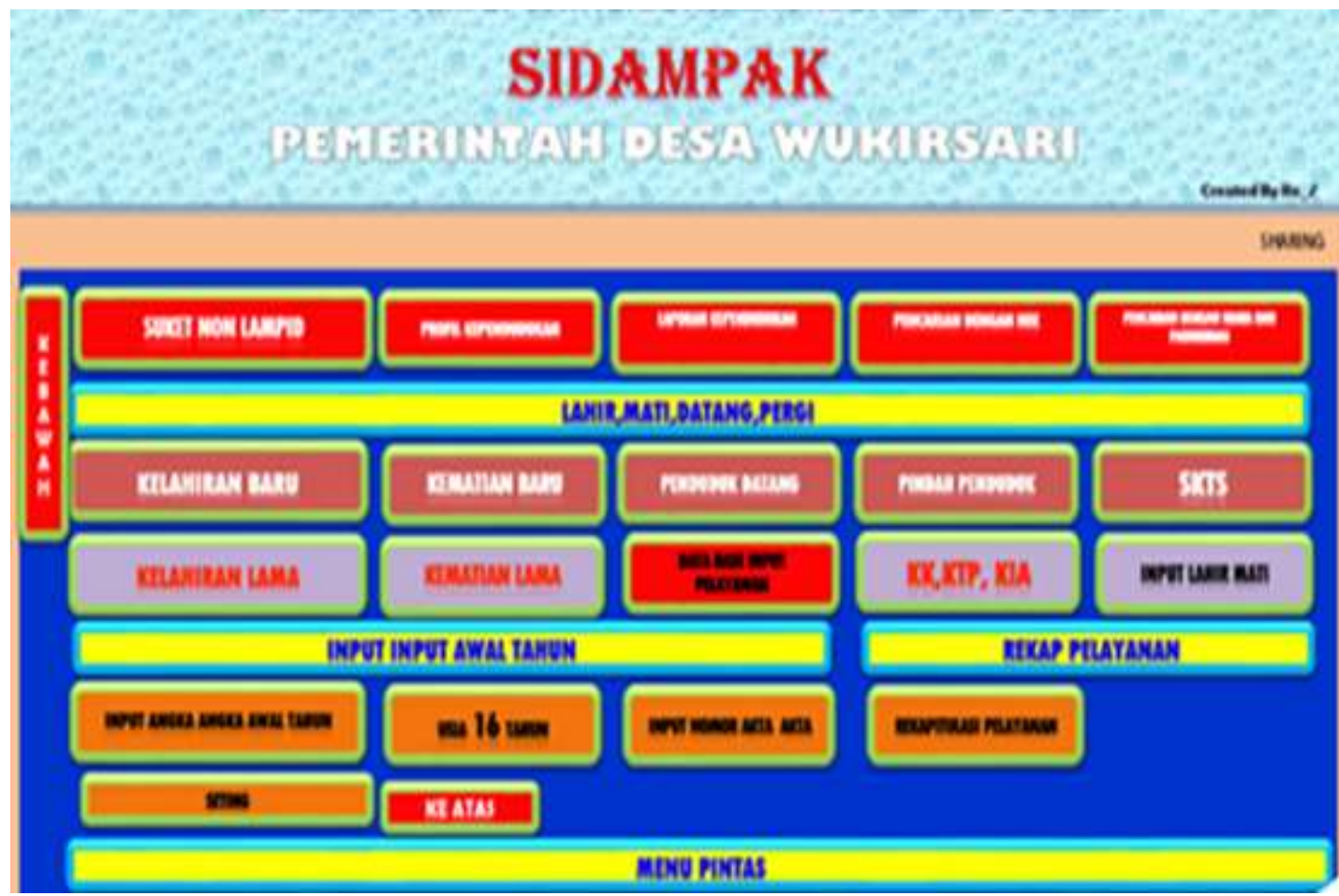

Figure 1. Application of the Wukirsari Government Sidampak Program

Meanwhile, the data base of population administration in the Sidampak program can be developed into:

a. Lukadesi Program (family grieving village alert)

This program aims to provide services to the community in the form of submitting death certificates, condolences from the village administration, and quotations of death certificates at the time of departure of the body. In addition, the village government also provided notification of when a joint prayer event 
Proceeding ICOGISS 2019

Page: 362-372 ISBN: 978-602-6 988-75-1

Web Jurnal Online: jurnal.unmuhjember.ac.id

By: Hanantyo Sri Nugroho

Government Glocalization As An Public Service Innovation In Wukirsari Village,

Sleman Regency

was held for families left in accordance with the usual period. This was then felt to provide benefits for the people of Wukirsari village who had a habit of praying together after the body was buried, namely 7 days, 40 days, 100 days, and 1000 days. In the lukadesi program, information media for reporting that can be used in the form of SMS, social media, telephone calls delivered by the Head of the District to the Government of Wukirsari Village service. Meanwhile, the Lukadesi program of the Wukirsari Village Government was conducted in 2015. Furthermore, this program has been duplicated by 60 villages in Sleman Regency.

b. My birthday program

This program is an innovation of community service aimed at children who have an age of 17 years. This means that the Wukirsari Village Government gives a happy birthday notification letter to the child through the physical and soft files distributed to the head of hamlet. It is intended that citizens who will be 17 years old can immediately carry out the electronic KTP recording process. The output of this program increases the awareness of citizens to record population through electronic KTP. Meanwhile, my birthday program began in 2015.

c. Birth data services

The birth data service program is an innovation of service to the community in storing data in the form of monthly, semester, and annual statistics. The program provides benefits to the details of the number of babies born, average baby weight, average length, average age of the parent, gestational age, surgical process through surgery or normal, the gestational age of the baby including premature or normal, up to funding sources birth process.

d. Public service and population hotline

A hotline is provided for the people of Wukirsari village who wish to service the application for general statements, population papers, as well as consultation on population affairs and public services. This aims to help and facilitate the Wukirsari village community in conducting population administration. Meanwhile, the public service and population hotline has begun in 2015.

e. Facilitation of Death and Birth Deeds

This death and birth certificate facilitation service is a service provided to the community in obtaining a birth certificate / death certificate, leminating deed, legalizing a deed 4 . This service is given to the village community of Wukirsari without imposing costs on the community. Meanwhile, this facility began in 2015.

f. Data services moved residents and residents to come

This service is given in connection with data on residents moving and residents coming. In addition, this service also provides services for the delivery administration to move residents and residents to come. Meanwhile, data on population and population movements are documented periodically, namely daily and monthly.

g. Service statistics on diseases that cause death 
Proceeding ICOGISS 2019

Page: 362-372 ISBN: 978-602-6 988-75-1

Web Jurnal Online: jurnal.unmuhjember.ac.id

By: Hanantyo Sri Nugroho

Government Glocalization As An Public Service Innovation In Wukirsari Village,

Sleman Regency

This service provides data related to the type of disease that causes the death of the Wukirsari Village community. This is useful for extension workers and preventive actions carried out by the Wukirsari Village Government.

h. The service of recapitulation statistical data where residents are buried

This service provides data related to the recapitulation of where the residents of Wukirsari Village are buried. In addition, the data can also read the density of a tomb in the village of Wukirsari. This is useful for input into planning the management of tombs in the village of Wukirsari.

i. Statistical service for recapitulation of the time of reporting of deaths and births in each hamlet

This service provides an overview related to the average length of time reporting of deaths and births in each hamlet. It is also beneficial for the village government and the people of Wukirsari village in seeing the performance of the head of hamlet in providing services for reporting deaths and births.

Furthermore, Sidampak's innovation also initiated other uses, namely Sidampak as data processing, Sidampak as the administration of village assets, Sidampak as a community satisfaction index data processing system (IKM), Sidampak as a population administration data base information system, Sidampak as a marriage registration administration system (Sidanik) Meanwhile, Sidampak's innovation funding support is as follows:

- APBDes in 2015 amounted to Rp. 16,339,885, -

- APBDes in 2016 amounted to Rp. 12,205,000, -

- APBDes in 2017 amounted to Rp. 239,442,500, -

- APBDes in 2018 amounted to Rp. 85,051,000, -

Thus, the Sidampak program has improved the quality of public services in the Wukirsari Village Government. In terms of service policy, the Sidampak program has set service standards and included the involvement of the Wukirsari Village community in providing input to stakeholders in the Wukirsari village government about the concept of service desired by the community. Furthermore, with the Sidampak program, it has been shown that service providers with competencies are in accordance with the needs of the type of service and the readiness of service providers in providing services that are responsive to service time. Moreover, there is an update of data and information related to population administration services in Wukirsari Village. In addition, front office facilities are also available for face-to-face consultation and information services for the people of Wukirsari village related to the administration of population administration. This can also be used as a means of consultation and complaints. The following is a picture of the general service section of the Wukirsari Village Government 
Proceeding ICOGISS 2019

Page: 362-372 ISBN: 978-602-6 988-75-1

Web Jurnal Online: jurnal.unmuhjember.ac.id

By: Hanantyo Sri Nugroho

Government Glocalization As An Public Service Innovation In Wukirsari Village,

Sleman Regency

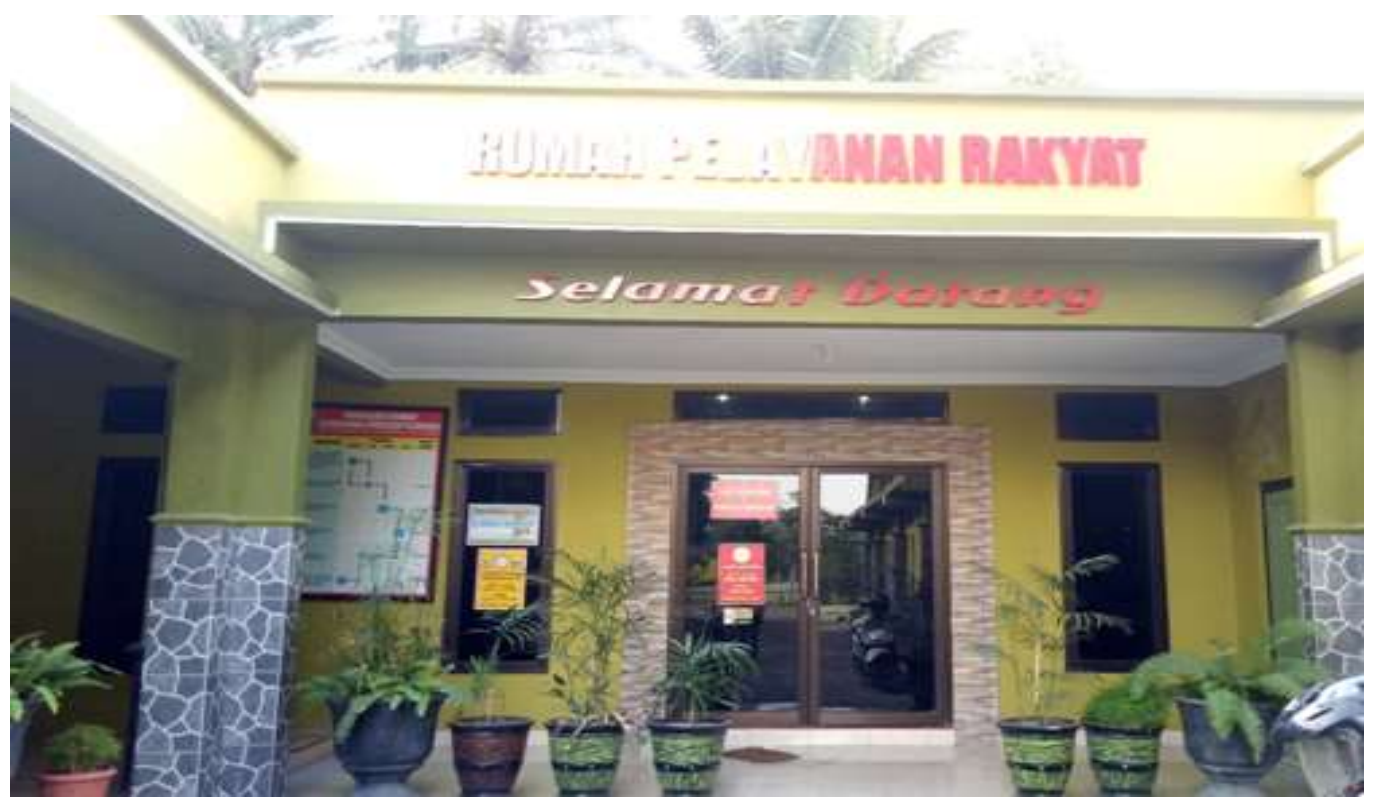

Figure 2. Public Service Section of the Government of Wukirsari Village

In an interview with the Wukirsari Village government, the Sidampak Program was a program created by the Head of Administrative and General Affairs of the Wukirsari Village Government. This head of administrative and general affairs became the actor of change in the administration of population administration in the village of Wukirsari. This change is based on village community input and the desire of the head of administrative and general affairs in providing easy and fast services to the community. Therefore, the head of administrative and general affairs wants to create a system that can complete 18 administrative and public works. That is, at the stage of making the Sidampak program, the head of administrative and general affairs is strongly influenced by practical awareness in formulating community service innovations in the form of Sidampak program.

Furthermore, innovation in community service in the form of the Sidampak program can change the pattern of community activity in managing population administration. The data shows that there has been an increase in the community in managing death certificates which have now reached $99 \%$, which is different at the time when there is the emergence of the Sidampak program which is $2 \%$ (in an interview with Ma'ruf, 2019). This then became the driving force for the head of administrative affairs and the general government of Wukirsari village in carrying out further innovations from the Sidampak program. At this time, changes to the Sidampak program have entered the fourth version.

In the development of the Sidampak program development process, the attitude of the head of administration and general affairs then began to build a critical awareness that the Sidampak program could be developed into a monitoring mechanism for village government officials related to population administration interests. Meanwhile, the existing data is further analyzed in more detail by the administrative and general affairs of the Wukirsari village government related to the causes of the obstacles to population 
Proceeding ICOGISS 2019

Page: 362-372 ISBN: 978-602-6 988-75-1

Web Jurnal Online: jurnal.unmuhjember.ac.id

By: Hanantyo Sri Nugroho

Government Glocalization As An Public Service Innovation In Wukirsari Village,

Sleman Regency

administration. As there is data on the level of population administration reporting that is often late reported, it is related to population data which often with social conditions, namely siri marriage. This can then be used as an analysis material used by other parts of the village government. Furthermore, here are the usage implications of the Sidampak innovation:

Table 1. Changes resulting from the innovation of Sidampak

\begin{tabular}{|l|l|l|}
\hline No & Circumstances before innovation. & Circumstances after innovation \\
\hline 1 & $\begin{array}{l}\text { Service culture still uses } \\
\text { conventional service patterns so that } \\
\text { it has not reached the ideal point of } \\
\text { community satisfaction. }\end{array}$ & $\begin{array}{l}\text { Services are carried out quickly, } \\
\text { according to SOP, served by } \\
\text { competent people, high level of data } \\
\text { accuracy, village government has } \\
\text { complete population data. }\end{array}$ \\
\hline 2 & $\begin{array}{l}\text { Public service in the village is only } \\
\text { as a recommendation (introduction) } \\
\text { where the settlement process is at } \\
\text { the sub district and dinas level. }\end{array}$ & $\begin{array}{l}\text { The emergence of interest from other } \\
\text { departments and villages in applying } \\
\text { or adopting the system from the } \\
\text { Sidampak Program and village } \\
\text { government can position itself as } \\
\text { community service. }\end{array}$ \\
\hline 3 & $\begin{array}{l}\text { The lack of public awareness of } \\
\text { ownership of population documents } \\
\text { is due to poor governance of } \\
\text { government services to the } \\
\text { community. }\end{array}$ & $\begin{array}{l}\text { The establishment of an orderly culture } \\
\text { of population administration for the } \\
\text { people of Wukirsari village. }\end{array}$ \\
\hline
\end{tabular}

\section{CONCLUSION}

The Population Data Collection System (Sidampak) in Wukirsari Village is a population administration service program that has provided many benefits. The background of the absence of a clear plan in the development of services to the community and the low level of community participation in ownership of population administration documents which later became the basis for creating a population administration service system that can provide complete, accurate, fast, easy and integrated results. This then gave rise to consequences for the Wukirsari village government in making public service innovations. The innovation is not only to the value of fast, easy, cheap, but more to the value of services that are tailored to the culture of Wukirsari society. One of them is the lukadesi program and my birthday program. The program then changed the innovation of public services more in accordance with the social conditions of the village community. This then became a pressure point for the activity of citizens in managing population administration in the village of Wukirsari.

In terms of service policy, the Sidampak program has set service standards and included the involvement of the Wukirsari Village community in providing input to stakeholders in the Wukirsari village government about the concept of service desired by the community. Furthermore, with the Sidampak program, it has been shown that service providers with competencies are in accordance with the needs of the type of service and 
Page: 362-372 ISBN: 978-602-6 988-75-1

Web Jurnal Online: jurnal.unmuhjember.ac.id

By: Hanantyo Sri Nugroho

Government Glocalization As An Public Service Innovation In Wukirsari Village,

Sleman Regency

the readiness of service providers in providing services that are responsive to service time. Moreover, there is an update of data and information related to population administration services in Wukirsari Village. In addition, front office facilities are also available for face-to-face consultation and information services for the people of Wukirsari village related to the administration of population administration. This can also be used as a means of consultation and complaints.

Furthermore, the Sidampak Program is a program created by the Head of Administrative and General Affairs of the Wukirsari Village Government. This head of administrative and general affairs became the actor of change in the administration of population administration in the village of Wukirsari. This change is based on village community input and the desire of the head of administrative and general affairs by wanting to change population administration services so that they can provide easy and fast services to the community. in formulating community service innovations in the form of Sidampak program. In the development of the Sidampak program development process, the attitude of the head of administrative and general affairs began to develop a critical awareness that the Sidampak program could be developed into a monitoring mechanism for village government officials related to population administration interests. Meanwhile, the existing data is further analyzed in more detail by the administrative and general affairs of the Wukirsari village government related to the causes of the obstacles to population administration, and can be used as material for analysis used by other parts of the village government. 
Proceeding ICOGISS 2019

Page: 362-372 ISBN: 978-602-6 988-75-1

Web Jurnal Online: jurnal.unmuhjember.ac.id

By: Hanantyo Sri Nugroho

Government Glocalization As An Public Service Innovation In Wukirsari Village,

Sleman Regency

\section{REFERENCE}

JPIP, The Jawa Pos Institute of Pro Otonomi. (2017). dalam http://roorganisasi.jatimprov.go.id/images/unduh_materi/Teknik\%20Menulis\%20Proposa 1\%20Inovasi\%20\%20Pelayanan\%20Publik_Wawan\%20Sobari.pdf, yang diakses pada 13 Maret 2019

Pemerintah Desa Wukirsari. 2018. Inovasi Pelayanan Masyrakat dan Sistem Administrasi Dalam Rangka Peningkatan Kualitas Pelayanan Publik Serta Pelayanan Administrasi.

Peraturan Menteri Pendayagunaan Aparatur Negara dan Reformasi Birokrasi Republik Indonesia tentang Pedoman Penilaian Kinerja Unit Penyelenggara Pelayanan Publik. 2017. Diunduh pada https://jdih.menpan.go.id/data_puu/final\%2017.pdf, yang diakses pada 04 Maret 2019

Milles, Mattew B. dan A. Michael Huberman. 1994. Qualitative Data Analysis: An Expanded Sourcebook. New Delhi: SAGE Publications.

Moleong, Lexy J. 2002. Metodologi Penelitian Kualitatif. Bandung: PT. Remaja Rosdakarya.

Muhadjir, Noeng. 2000. Metodologi Penelitian Kualitatif. Yogyakarta: Rake Sarasin. 